\title{
Bogdan Nawroczyński - uczony, humanista, wychowawca. Sesja naukowa na Wydziale Pedagogicznym Uniwersytetu Warszaw- skiego (25.X.1994)
}

Wydział Pedagogiczny Uniwersytetu Warszawskiego oraz Oddział Warszawski Polskiego Towarzystwa Pedagogicznego byli organizatorami jednodniowej sesji naukowej poświęconej temu wybitnemu pedagogowi.

Obrady otworzyli: prof. dr hab. Stefan Mieszalski - dziekan Wydziału Pedagogicznego UW oraz prof. dr hab. Alicja Anna Kotusiewicz - prezes Oddziału Warszawskiego PTP. Referaty przygotowali: prof. dr hab. Anna Mońko-Stanikowa (pt. „Bogdan Nawroczyński - Człowiek i Dzieło"), prof. dr Stefan Wołoszyn (nt. „Bogdana Nawroczyńskiego spór z Teodorem Littem o swobodę i przymus w wychowaniu”), prof. dr Wincenty Okon (pt. „Bogdana Nawroczyńskiego pedagogika słuźby”). „Zycie duchowe w ujęciu Bogdana Nawroczyńskiego” omówił dr hab. Stanisław Rucińskí, zaś „Autoportret pamiętnikarski profesora Bogdana Nawroczyńskiego" przedstawił dr Waldemar Kaminski.

W dyskusji głos zabrał m.in. prof. dr hab. Jan Hellwig. Wskazał on na owocną dla polskich nauk o wychowaniu, aczkolwiek stosunkowo krótka, działalność naukowo-dydaktyczną i organizacyjną prof. Nawroczyńskiego w charakterze kierownika Katedry Pedagogiki Uniwersytetu Poznańskiego (tutaj odbyl się Jego "start naukowy").

Moderatorami obrad byli prof. dr hab. Zbigniew Kwieciński i prof. dr hab. Anna Przecławska. Materiały stanowiące plon konferencji mają być wydane przez PTP.

\section{Spotkanie historyków wychowania w Krakowie}

W dniu 6 grudnia 1994 roku odbyło się w auli Wyższej Szkoły Pedagogicznej w Krakowie ogólnopolskie spotkanie historyków wychowania zorganizowane $\mathrm{z}$ okazji sześćdziesięciolecia urodzin i czterdziestolecia pracy zawodowej Profesora Zygmunta Ruty.

W pierwszej części obrad głównym ich przedmiotem był obecny stan i perspektywy rozwoju historii wychowania w Polsce. Wprowadzenie do dyskusji na ten temat przedstawił zebranym prof. dr hab. Karol Poznański, członek Prezydium Komisji Nauk Pedagogicznych Polskiej Akademii Nauk i przewodniczący Zespołu Historii Wychowania przy KNP. Podczas żywej dyskusji podejmowano m.in. problemy usprawnienia przepływu informacji w środowisku historyków wychowania, zagadnienia kształcenia i rozwoju kadry naukowej w dziedzinie historii wychowania, kwestie historii wychowania jako przedmiotu nauczania (w tym szczególnie sprawe malejącego wymiaru godzin przeznaczonych na zajęcia $z$ historii wychowania). Podkreślono znaczenie i możliwości badań w zakresie różnych problemów badawczych (dotyczących na przykład kultury staropolskiej, dziejów edukacji na wschodnich terenach).

Druga część spotkania poświęcona była wyłącznie Osobie Profesora Zygmunta Ruty. Profesorowi wręczono, dedykowany Jemu, czwarty tom „Prac z Historii Oświaty i Wychowania”, wydany - pod redakcją Jana Krukowskiego i Czesława Majorka - przez Wydawnictwo Naukowe WSP w Krakowie. Odrębne upominki i życzenia dla Jubilata przekazali również - licznie zgromadzeni w auli WSP - przedstawiciele wielu krajowych ośrodków naukowych. 
W trzeciej części spotkania omówiono przygotowania do XVIII Konferencji ISCHE w Krakowie. Prowadzący tę część obrad prof. dr hab. Czesław Majorek przedstawił m.in. założenia organizacyjne i zarys programu konferencji, planowane koszty udziału w konferencji (proponowaną wysokość opłaty rejestracyjnej - na poziomie 200 USD), plan dalszych prac przygotowawczych. Wiele kontrowersji wzbudził problem interpretacji okresu modernizmu i postmodernizmu w odniesieniu do polskiego procesu historycznego. Żywą dyskusję wywołala także kwestia wnoszenia opłaty rejestracyjnej (w proponowanej wysokości) przez uczestników z Polski.

Spotkaniu towarzyszyła wystawa prac Profesora Zygmunta Ruty. Ukazywała ona Jego szeroki dorobek publikacyjny, obejmujący dzieje wychowania w rozległej perspektywie chronologicznej: od okresu staropolskiego aż do najnowszej historii Polski (w szczególności publikacje będące rezultatem Jego badań nad staropolskim szkolnictwem i wychowaniem, dziejami kształcenia nauczycieli, szkolnictwem II Rzeczypospolitej oraz publikacje łączące się z - wyraźnie wyodrębniajacym się $w$ pracy badawczej Profesora - nurtem badań regionalnych). Wystawa prezentowała zarówno autorskie opracowania Profesora, jak i prace współautorskie czy redakcyjne.

\section{Profesor Bogdan Suchodolski - uczony, filozof, czlowiek widziany z perspektywy przelomu wieków (Sesja naukowa (15-16.XII.1994)}

W Pałacu Staszica w Warszawie, siedzibie Polskiej Akademii Nauk odbyla się sesja naukowa pod powyższym tytułem. Organizatorem był Zarząd Główny Polskiego Towarzystwa Pedagogicznego.

Głównym celem sesji było stworzenie płaszczyzny dla podjęcia głównych wątków zainteresowań naukowych prof. Bogdana Suchodolskiego (1903 - 1992) i dostarczenie okazji do wszechstronnego spojrzenia na twórczość Profesora i Jego wielostronną działalność naukową, społeczno-kulturalną i polityczną. Podczas tego spotkania wyjaśniono także szereg kwestii niejasnych i kontrowersyjnych, dla których oświetlenia powstał obecnie odpowiedni klimat, np. związanych z działalnością w Narodowej Radzie Kultury.

Podstawowe referaty wyglosili:

- prof. Stefan Wołoszyn - Przebudowa podstaw nauk humanistycznych i udział w niej Profesora Bogdana Suchodolskiego;

- prof. Irena Wojnar - Humanizm - mimo wszystko (człowiek i świat człowieka);

- prof. Jan Szczepański - Związki między kulturą a edukacją w ujęciu Bogdana Suchodolskiego;

- prof. Wincenty Okoń - Wychowanie a strategia życia w ujęciu Bogdana Suchodolskiego;

- prof. dr Czeslaw Kupisiewicz - Kształcenie dla przyszłości w ujęciu Bogdana Suchodolskiego;

- prof. Władysław Markiewicz - Obecność Profesora Bogdana Suchodolskiego w polskim życiu naukowym.

Referaty uzupełniające przedstawili i głos w dyskusji zabrali również: prof. Grzegorczyk, prof. Kazimierz Żygulski, prof. Dzierżymir Jankowski, dr Jerzy Kubin, prof. Jan Hellwig (pt. Bogdan Suchodolski jako historyk wychowania), prof. Janusz Gajda, doc. Wiesława Pielasińska, dr Stanisław Majewski (nt. Wkład B. Suchodolskiego do historii wychowania), dr Waldemar Kamiński, prof. Bogusław Chmielowski, dr Janusz Ruciński, prof. Góralski.

Moderatorami obrad byli prof. Zbigniew Kwieciński (prezes PTP), prof. Helena Kwiatkowska (wiceprezes PTP) i prof. Irena Wojnar. Materiały z sesji zostaną opublikowane przez organizatora. 